\title{
KIRJOITUS
}

ANU MORIKAWA

\section{Ilmastonmuutos ja minä - Ahdistaako? Kooste Aalto-yliopiston opiskelijoille suunnatusta pilotista}

Y

mpäristöahdistus on ympäristöongelmien henkinen seuraus. Ympäristöasioiden henkisten ja hengellisten ulottuvuuksien käsittelyyn käytetään monenlaisia keinoja jo nyt, mutta mitään valmista materiaalia ei ollut saatavilla, kun Aalto-yliopiston oppilaitospappi Anu Morikawan (Espoon seurakuntayhtymä) ja Aalto-yliopiston opintopsykologi Sanni Saarimäen toimesta lähdettiin toteuttamaan pilottia Ilmastonmuutos ja minä-Ahdistaako? (syksy 2017-kevät 2018). Herkkiä ja henkilökohtaisia aiheita on käsiteltävä vastuullisesti. Tähän tarpeeseen muodostettu pilotti oli suunnattu Aalto-yliopiston opiskelijoille. Tarjolla oli paitsi vertaistukea myös tunteiden tunnistamista ja sanoittamista, toisen kuuntelemista, omien ajatusten sanoittamista ja työvälineitä näiden vaikeiden teemojen käsittelyyn.

1990-luvun ala-asteen oppikirjoissa on käsitelty teemaa kasvihuoneilmiö. Opetettiin, että sääolosuhteet ovat muuttuva ilmiö, ilmasto ei. Nykytiedon valossa asia ei ole ollenkaan näin yksinkertainen. Viiden kerran kurssikokonaisuudessa lähdettiin liikkeelle siitä, että ilmastonmuutos on totta ja on jo täällä. Painotetut kysymykset olivat; Miten elää tämän tiedon kanssa? Miten kohdata tämän tiedon valossa koetut tunteet?

Kyseessä oli pilotti, jossa keskusteltiin ilmastonmuutokseen liittyvistä ajatuksista ja tunteista. Ryhmä ei ollut terapiaa, eikä se soveltunut akuutissa kriisissä olevalle. Ryhmä oli katsomuksellisesti sitoutumaton.

Pilotti koostui viidestä kokoontumiskerrasta seuraavien teemojen mukaan: 
1. Mitä on ilmasto- ja ympäristöahdistus?

2. Tunteet ja toiminta

3. Epätoivo, toivo ja toivottomuus

4. Miten ilmastoahdistusta voi purkaa?

5. Mistä valoa tulevaan?

Toimme alkuinfossa esille, että tulemme keskustelemaan luottamuksellisessa ilmapiirissä tulevaisuudesta, sen herättämistä uhkakuvista ja toivonpilkahduksista. Kerroimme, että kurssilla pohditaan oman ahdistuksen suhdetta toimintaan ja kuullaan ilmasto- ja ympäristöasiantuntijoiden kokemuspuheenvuoroja. Sanoitimme, että meillä ei ole tarjota valmista ratkaisua ilmastoahdistukseen, mutta eväitä, tukea ja työkaluja saat. Avain ilmastonmuutoksen ratkaisemiseen on meissä jokaisessa, mutta se ei tapahdu ilman vaikeiden tunteiden kohtaamista. Kurssikirjeessä kerroimme asiasta näin:

Ilmastonmuutos on fakta, joka herättää ihmisissä monenlaisia ajatuksia ja hankalia tunteita; ahdistusta, pelkoa, vihaa, ärtymystä, surua ja kaikkea näiden väliltä. Ilmastonmuutokseen liittyy myös monenlaisia henkilökohtaisen elämän kokemuksia, ehkä syyllisyyttä, syyttelyä, taistelua ja lamaantumista, mutta myös sisuuntumista ja merkityksellisyyden etsintää. Toinen kokee ilmastoahdistusta voimakkaasti, toinen vähemmän. Elämäntilanteet ja omat lähtökohdat vaihtelevat. Joku on "kasvanut" asian parissa, toinen ehkä havahtunut asian vakavuuteen vasta hiljattain. Joku osaa nimetä ilmastonmuutoksen itsessä herättämiä reaktioita helposti, toinen vielä etsii sopivia sanoja ja omaa suhdettaan tähän kaikkeen. Joku toivoo muuttavansa maailmaa, toinen haluaisi löytää edes pienen palan, mihin keskittyä omassa arjessaan. Moni meistä unelmoi, että koko ilmastonmuutos olisi jotain, mihin ei tarvitsisi reagoida, jotain minkä voisi jättää kohtaamatta kokonaan. Moni meistä toivoo myös, että ratkaisut voisivat tapahtua nopeammin, ja ehkä jossain itää siemen siitä, että pääsisi jotenkin itse tekemään osansa. Kaikki nämä ja mikä tahansa muu lähtötilanne on täysin sallittu. (Kurssimateriaali, 2017.)

Kurssikokonaisuudessa hyödynnettiin metodiikkaa esimerkiksi hyväksymisja omistautumisterapiasta, mindfulnessista ja kriisipsykologiasta. Tällaisessa työskentelyssä ryhmän ohjaajalla on hyvä olla taustallaan kokemusta ryh- 
mänvedosta ja pedagogiikasta sekä ymmärrystä ryhmädynamiikasta ja tunneprosesseista sekä yksilö- että ryhmänäkökulmasta. Ohjaajien on hyvä olla perillä omasta roolistaan, toiveistaan ja ennakko-oletuksistaan sekä toistensa työskentelytavoista. Omat piiloagendat ja toiveet siitä, miten ryhmän jäsenten tulisi toimia maailmassa on käsiteltävä etukäteen. Turvallisen ilmapiirin luominen, luottamuksen herättäminen, vertaistuen mahdollistaminen ja hyvät ryhmänohjaustaidot ovat ne elementit, joita ryhmää ohjaavalta työntekijältä voidaan edellyttää. Kaikenlainen vähättely, yläpuolelle asettuminen tai epäaitous tuo ilmapiiriin haittaavia elementtejä ja kurssin hyöty voi jäädä teoreettiselle tasolle. Kurssin ohjaajat kiinnittivät erityistä huomiota näihin seikkoihin. Jokainen kokoontumiskerta sisälsi sekä toiminnallisia menetelmiä että varsinaisia keskusteluja pareittain, pienryhmissä ja koko porukan kesken. Toiminnalliset menetelmät olivat vaihtelevasti joko kiertokävelyitä, tunteiden ja tunnelmien määrittelyjä, eläytymistehtäviä tai mindfulnessia.

\section{Kirkon ilmastostrategia viitoittamassa ilmastokysymysten äärellä tehtävää työtä}

Suomen evankelis-luterilainen kirkko on merkittävässä roolissa, kun luodaan uskoa ja luottamusta tulevaan. Tähän liittyy vahvasti myös kirkon ilmastostrategia Hiilineutraali kirkko (2019). On tärkeää, että kirkko asettuu sen tosiasian taakse, että ilmastonmuutos on maailmanlaajuinen kriisi, joka vaikuttaa näkyvästi koko luomakunnan elämään. Kirkko instituutiona ei peräänny, ei vähättele eikä pakene tätä faktaa. Energia- ja ilmastostrategian konkreettisten tavoitteiden avulla Suomen evankelis-luterilainen kirkko sitoutuu hillitsemään ilmastonmuutosta ja edistämään kestävää elämäntapaa. Kirkon ilmastostrategiassa todetaan seuraavaa:

Ilmaston lämpeneminen, luonnon monimuotoisuuden katoaminen ja ekosysteemin vaurioituminen kytkeytyvät suoraan elämäntapaamme. Elämäntapojen takana ovat puolestaan ajattelutavat, jotka liittyvät arvoihin. Kirkon erityiset vahvuudet ilmastotyössä voisivat olla juuri arvoissa ja asenteissa. (Hiilineutraali kirkko, 2019.)

Arvot, jotka ovat kirkon energia- ja ilmastostrategian taustalla, nousevat kirkon ilmasto-ohjelmasta vuodelta 2008 (Kiitollisuus, kunnioitus, kohtuus, 
2008). Siinä korostuvat kiitollisuus, kunnioitus ja kohtuus. Näistä arvoista todetaan, että kiitollisuus Jumalan luomakuntansa kautta antamista elämän lahjoista saa tuntemaan kunnioitusta, joka ohjaa kohtuullista elämäntapaa ja toisaalta elämäntapaa, joka mahtuu planeetan puitteisiin. Kirkon ilmasto-ohjelman perusteella monien ihmisten tulee vähentää kulutustaan ja sopeuttaa elämänsä kohtuullisiin puitteisiin ja samaan aikaan monet tarvitsevat nykyistä enemmän. Kristilliset kirkot yhdessä monen muun uskonnon kanssa ovat korostaneet vuosisatojen ajan, että kun tietyt perustarpeet on tyydytetty, todellinen elämän ilo tulee rakkaista ihmisistä ja meitä ympäröivän luomakunnan rikkaudesta. Evankelis-luterilainen kirkko kannustaakin luoviin ratkaisuihin ja ilmastoystävälliseen ajattelutapaan muun muassa Kirkon ympäristödiplomin kautta (Kirkon ympäristödiplomin käsikirja, 2012).

Hiilineutraali kirkko -strategiassa todetaan, että konkreettisilla toimilla kirkko on toivon kantaja. Ilmastoahdistuksen ja pessimismin keskellä kirkko haluaa luoda toivoa ja innostaa kirkon jäseniä ja muita ihmisiä työhön ilmastonmuutoksen hillitsemiseksi. Kirkko rohkaisee ja haastaa paitsi jäseniään, myös muita yhteiskunnallisia toimijoita ja päättäjiä mukaan ilmastotyöhön ja hiilineutraaliustavoitteisiin. Strategian tavoitteissa todetaan muun muassa, että kirkko vaikuttaa aktiivisesti yhteiskunnallisena toimijana ja keskustelijana. Suosituksena on, että kirkko rohkaisee ja haastaa viestinnässään ja toiminnassaan jäsenensä mukaan ilmastotyöhön ja hiilineutraaliustavoitteisiin. Myös rippikouluun osallistuneet tulevat tiedostamaan ilmastovastuunsa ja tähän pyritään muuan muassa sillä, että rippikouluja toteutetaan ympäristöystävällisesti (Vihreät riparit -kriteerit). Kirkko vaatii myös päättäjiltä rohkeita ilmastotoimia ja sitä, että seurakunnat tekevät yhteistyötä toisten seurakuntien, kuntien, kaupunkien, järjestöjen ja muiden sidosryhmien kanssa ilmastotavoitteiden saavuttamiseksi. Kirkko haluaa olla edistämässä globaalia ilmasto-oikeudenmukaisuutta. (Hiilineutraali kirkko, 2019.)

\section{Ympäristöahdistuksesta ympäristösuruun}

Kun Ilmastonmuutos ja minä - Abdistaako? -kurssin pilotti alkoi hahmottua syksyllä 2017, puhuttiin enemmän ympäristöahdistuksesta, mutta vuonna 2018 vakiintuneeseen käyttöön tuli termi ilmastoahdistus. Tässä lyhyessä ajassa nämä termit vakiintuivat myös mediassa ja uutisointi aiheen ympäriltä lisääntyi. Myös Aalto-yliopistossa toteutettu pilotti sai osansa, kun mm. YLE 
otti yhteyttä ja toivoi voivansa osallistua radiotoimituksen keinoin kurssille. Pitkän pohdinnan päätteeksi kurssin vetäjät eivät antaneet tähän mahdollisuutta luottamuksellisen ilmapiirin säilyttämiseksi. Aalto-yliopiston opintopsykologi Sanni Saarimäki lupautui kuitenkin lukuisiin haastatteluihin ja kertoi näissä yhteyksissä myös tästä kurssipilotista (Yle.fi, 2018; 2019a; 2019b).

Suomessa keskustelu ilmastoahdistuksesta lisääntyi syksyn 2017 jälkeen, jolloin ilmestyi myös teokset Hyvän sään aikana (Nikkanen \& työryhmä, 2017) sekä Päin helvettiä? Ympäristöahdistus ja toivo (Pihkala, 2017). Lisäksi kurssin opiskelijat laativat yhdessä kolumnin Rakas ilmastonmuutos (2018), joka julkaistiin Aalto University Magazinessa keväällä 2018. Ilmastonmuutos ja minä-Abdistaako? on tiettävästi Suomen ensimmäinen keskusteluryhmä aiheesta.

Ilmastoahdistus tarkoittaa ahdistustilaa, jossa henkilö kokee ilmastonmuutokseen liittyvien asioiden uhkaavan häntä. Ilmastoahdistus tai ilmastonmuutosahdistus on merkittävä osa ympäristöahdistuksen ilmiötä. Ilmastonmuutokseen liittyvät psyykkiset vaikutukset nähdään käsitekartassa ilmastoahdistuksena. Nämä vaikutukset voivat olla joko suoria tai epäsuoria. Ilmastonmuutoksen suoria vaikutuksia on tutkittu enemmän kuin epäsuoria. Ilmastonmuutoksen aiheuttamat tai pahentamat luonnonkatastrofit aiheuttavat esimerkiksi ahdistusta, posttraumaattista stressiä, masennusta ja vahingollista käyttäytymistä. Yksi ilmastonmuutoksen epäsuora vaikutus on se, että ihminen ei vielä itse kärsi suoraan kovin paljon ilmastonmuutoksen fyysisistä vaikutuksista, mutta kokee silti huomattavaa psyykkistä kuormitusta. Voidaan nähdä, että ilmastonmuutos on lukuisille ihmisille keskeinen tulevaisuuteen liittyvä uhkakuva, minkä vuoksi ilmastoahdistuksen yksi peruspiirre on tulevaisuuteen liittyvä pelko ja huoli (Pihkala, 2019).

Tulevaisuuden uhkakuviin liittyen ajatukset voivat liikkua lähelle kuolemaa, elämän päättymistä ja maapallon tuhoutumista. Kun ympärillä olevaa luontoa tuhoutuu se voi puolestaan tuoda esille surua, jota voidaan kutsua ympäristösuruksi. Ympäristösuruun liittyen voidaan tässä yhteydessä todeta Pihkalan käyttäneen vertauskohtana toimivia suruprosesseja esimerkiksi silloin, kun outo valoisuus valtaa alaa hautajaisten jälkeen. Maailma ei ole entisellään, mutta siinä alkaa nähdä taas jotakin hyvää.

Pihkala (2017) käyttää termiä ympäristöahdistus kuvatessaan monenlaisia henkisiä oireita, joita ihmisillä on ympäristöongelmiin liittyen. Pihkala (2017:20-21) sanoittaa: 
Vaikka ahdistuksessa on kyse henkisestä asiasta, ihminen on kokonaisuus ja henkiset asiat nivoutuvat monin tavoin yhteen ruumiillisuuden kanssa. Tämä kokonaisvaltaisuus on erityisen merkityksellistä suhteessa luontoon, sillä ihmisen ruumis on ilmiselvästi yhteydessä ekosysteemeihin.

Sekä yksilöiden että yhteiskunnan kannalta olisi tärkeää, että ihmiset saisivat riittävästi tukea, jotta he uskaltaisivat tuoda surun tuntemuksia esiin. Ympäristösurua voi kokea eri tavoin. Jokainen joutuu kohtaamaan jonkinlaisen luopumisprosessin ympäristötuhojen aikana. On sopeuduttava tilanteeseen, jossa fossiiliset polttoaineet hupenevat, ympäristöpakolaisia on entistä enemmän ja yhteiskunnalliset olot vaativat kamppailua ihmisarvon puolesta. Kaikenlaista kipua ja surua tulisi kunnioittaa kohtaamalla, ei pakenemalla. (Pihkala, 2017:167-169.)

Pihkala (2017) korostaa, että suostuminen ja uskaltautuminen ovat olennaisia sanoja suruprosessissa. Hän painottaa, että tehtävämme on myöntää, että emme hallitse kaikkea. Pihkala näkee surun kuitenkin transformatiivisena - se voi muuttaa meitä ja maailmaa. Suru on sekä yksilöllinen että yhteisöllinen asia. Vertaistuki voi helpottaa, lohduttaa ja auttaa jaksamaan. Surua ei saa vähätellä tai selittää liian helposti pois. Tämä koskee myös ympäristösurua. Surua ylipäätänsä ilmaistaan hyvin kokonaisvaltaisesti. Pihkala painottaa, että se mitä suremme ja mitä emme, kertoo siitä, millaisia ihmisiä olemme. Näin ollen myös surulla on eettinen ulottuvuus ja surun salliminen on lopulta oikeuksiin liittyvä asia.

Ympäristöahdistuksen skaalan yhdessä ääripäässä ovat lääketieteellisesti määritellyt ahdistushäiriöt, joihin ympäristöhuoli on merkittävästi vaikuttanut. Osa ihmisistä saa akuutteja psykofyysisiä oireita, kuten vatsakipua, päänsärkyä tai unettomuutta, kun he kuulevat uutisia ympäristöön ja luontoon liittyvistä tuhoista. Psykologit ovat suositelleet seuraamaan esimerkiksi seuraavan kaltaisia alustavia oireita liittyen ympäristöahdistukseen; unihäiriöt, mielialan vaihtelut, ylivirittyneisyys, energiatasojen vähentyminen. (Pihkala, 2019.)

\section{Teologisia huomioita}

Kun puhumme ilmastoahdistuksesta, emme voi sivuuttaa kysymyksiä elämän merkityksellisyydestä, ihmisen olemassaolon oikeutuksesta, vastuullisuudesta (viljele ja varjele), kaiken katoavaisuudesta, kuoleman ja lopullisuuteen liitty- 
vistä pohdinnoista. Kirkon työntekijältä voidaan myös kysyä mikä on kirkon rooli tässä kokonaisuudessa, miten hengellisesti voi itsensä asemoida luomakunnan tuhoutumisen tilaan, mistä toivoa tulevaan, mihin uskoa, miten Jumala sallii tämän?

Suomen Mielenterveysseuran julkaisussa Ilmastoabdistus ja sen kanssa eläminen (Pihkala, 2019) todetaan, että ilmastoahdistuksen kohtaamistaitojen edistäminen vaatii sellaisen kulttuurisen muutoksen tukemista, jonka myötä tunnemyönteisyys kasvaa. Kliininen psykologi Maria Ojala on kehittänyt elämän merkityksellisyyden tunnon kasvattamiseen ja ylläpitämiseen keskittyvää mallia (meaning-focused coping, Ojala, 2012; Pihkala, 2019). Olennainen piirre merkityksellisyyteen liittyen on erottelu toiveajattelun ja rakentavan toivon välillä. Toiveajattelu voi hetkellisesti auttaa ahdistuksen sietämisessä, mutta pidemmällä tähtäimellä se on tuhoisaa sekä ekologisen kriisin että ihmismielen kestävyyden kannalta. Sekä Ojala että Pihkala ovat lähestyneet ilmastoahdistusta sekä käytännön tilanteisiin liittyvänä ahdistuksena että niin kutsuttuna eksistenttiaalisena ahdistuksena. Eksistenttiaalinen ahdistus liittyy elämän ja kuoleman peruskysymysten kohtaamiseen. Nykyaikana ilmastonmuutos ja ekokriisi herättävät tällaisia kohtalon kysymyksiä. Merkityksellisyyden tai tarkoituksen kokemisen keskeisyys piirtyy esiin eteenkin ilmastoahdistuksen eksistentiaalisia ulottuvuuksia vasten. (Pihkala, 2019.)

Ilmastoahdistuksen ympärillä on hyvä ymmärtää uskontotieteellinen ja teologinen näkökulma, sillä äärimmilleen vietynä ilmastonmuutoksen ympärille voi syntyä uskontoa muistuttavia elementtejä. Tämän voi havaita vaikkapa siitä, millä tavoin teemaa ja sen ympärillä syntyviä ajatuksia ja tunteita sanoitetaan. Tässä piilee yksi vaaratekijä; ihminen voi jäädä hyvin yksin ahdistavan ja suuren teeman alle, mikäli ei löydä valoisia tai toivoa luovia näkökulmia aiheen ympäriltä tai kanssaihmisistä. Ilmastonmuutoksesta voi tulla elämää liiaksi hallitseva teema. Juuri siksi ilmastonmuutokseen liittyvien tunteiden sanoittaminen, vertaistuki, ymmärrys ja hyväksyntä ovat mielestäni keskeisiä voimavaroja, joita kurssi itsessään pystyi tarjoamaan. Ilmastonmuutos ja minä-Ahdistaako? -kurssilla oli tärkeää myös normalisoida tunteita, kannustaa toimintakyvyn ja hyvinvoinnin säilyttämiseen sekä omien voimavarojen kuulosteluun. Armollisuus lienee yksi termi, jolla tätä kokonaisuutta voisi kuvata. Tämä voi tarkoittaa, että aina ei ole voimavaroja tai mahdollisuuksia elää omien ihanteiden mukaan ja sekin pitäisi pystyä hyväksymään, sillä lamaantuminen olisi myös ympäristöasioissa tuhoavaa. 


\section{Toivo}

Parhaimmillaan tai oikeastaan pahimmillaan ilmastoasioissa fanaattisuus voi alkaa muistuttaa harrasta uskonnollisuutta. Uskonnollisuutta, jossa korostuu armottomuus, toivottomuus ja lopullisuus. Kristillisen uskon näkökulmasta juuri toivo on yksi keskeinen voimavara. Osa ihmisistä kokee ahdistavia tunteita nimenomaan ympäristötuhoihin liittyen. Ympäristöahdistus voi olla osa sitä alakuloisuutta tai angstia, joka liittyy koko maailman tilaan ja tulevaisuuteen. Kukapa haluaisi ajatella ahdistavia asioita? On ymmärrettävää, että moni ei halua tarttua ympäristöasioihin. Aihepiiri vaikuttaa synkältä. Synkkien asioiden ajatteluun sisältyy kuitenkin suuria vapautumisen ja jopa ilon mahdollisuuksia. Helpottaa, kun saa omia tunteita käsiteltyä (Pihkala, 2017:12). Pihkala muistuttaa, että ympäristötoiminta ei ole pelkkää luopumista, vaan sen kautta voi myös saada paljon. Se, että uskaltaa käsitellä omaa ja muiden keskeneräisyyttä vie meitä siihen suuntaan, että voimme rohkaistua kohtamaan elämän ambivalenssin: moniulotteisuuden ja ristiriitaisuuden. Meidän tulisi olla armollisia itsellemme ja toisillemme. Samalla meidän tulisi kannustaa itseämme ja toisiamme entistä kestävämpiin elämäntapoihin, joissa yhteiskunnallinen vaikuttaminen on aivan keskeinen osa. (Pihkala, 2017:15.)

Ilmastonmuutos ja minä-Ahdistaako? -kurssikokonaisuuden aikana vierailijana kävi muun muassa kirjan Zero Waste - jäähyväiset jätteille kirjoittanut Otso Sillanaukee (2018). Sillanaukee toimi hyvänä, inspiroivana esimerkkinä siinä, että ympäristökysymyksiin tarttuminen ei tarvitse tarkoittaa eristäytyneisyyttä, epäsosiaalisuutta tai köyhää elämää. Luopumisen kautta voi syntyä tilaa jollekin uudelle. Ympäristöystävällisen elämäntavan myötä voi löytää merkityksellisyyttä elämään. Sillanaukee kehottaa pysähtymään kysymyksen äärelle: mikä tuottaa minulle iloa? (Sillanaukee, 2018:11). Ilmastopohdintaan liittyy oleellisesti pohdinta laajemmin elämästä ja minuudesta. Kuka minä olen ja miten minä haluan elää?

Ensimmäisen kurssikokonaisuuden kolmannella kerralla, kurssin puolivälissä, aiheena oli epätoivo, toivo ja toivottomuus, ja vieraana oli monitieteellinen ympäristöasioiden tutkija Panu Pihkala. Tavoitteena oli, että kurssin edetessä olisi mahdollista huomata, että toivon merkkejä on olemassa runsaasti. Pihkala toi tähän keskustelun ja työskentelyn keinoin näkökulmia toivosta, toivottomuudesta ja epätoivosta. 
Ympäristöahdistuksen käsittely auttaa ihmisiä liittymään yhteen toisten kanssa käytännön ongelmanratkaisutyöhön. Surusta ja tuskasta huolimatta pääpaino on elämän hyvyydessä ja merkityksellisyydessä. Toivoon liittyy Pihkalan mukaan rohkeus, luottamus ja sitkeys. Elämässä erilaisten kausien esiintyminen kannattaa hyväksyä ja tämän eteen joutuu joskus tekemään paljon töitä. (Pihkala, 2017.)

Keskeistä olisi, että ilmastoahdistus voisi toimia merkittävänä voimavarana. Tämä edellyttää, että on mahdollista löytää yhdessä toisten kanssa riittävästi aikaa ja tilaa tunteiden käsittelyyn sekä riittävästi toimintamahdollisuuksia ilmastonmuutoksen hillitsemiseksi. Tutkimukset osoittavat, että Suomessa yleinen huoli ilmastosta on kasvanut, eteenkin nuorten keskuudessa ja monia esimerkkejä erilaisista ilmastoahdistuksen oireista on tullut esiin. Kaksi keskeistä psykologista tehtävää ilmastonmuutoksen suhteen on sopeutuminen muuttuviin olosuhteisiin eli toimintakyvyn ylläpito ja oman eettisen vastuun hyväksyminen. Tässä yhteydessä käytetään myös termiä resilienssi (mielen joustavuus, kimmoisuus), jolla tarkoitetaan juuri toimintakyvyn säilyttämistä muutosten keskellä. Keskeistä on, että ahdistava asia kohdataan, mutta sen alle ei muserruta. (Pihkala, 2019.)

\section{Lähteet ja kirjallisuus}

Hiilineutraali kirkko (2019). Suomen evankelis-luterilaisen kirkon ilmastostrategia. 26.2.2019. Helsinki: Kirkkohallitus. https://evl.fi/plus/yhteiskunta-ja-kirkko/ kestava-kehitys/hiilineutraali-kirkko viitattu 6.8.2019.

Kiitollisuus, kunnioitus, kohtuus (2008). Kiitollisuus, kunnioitus, kohtuus: Suomen evankelis-luterilaisen kirkon ilmasto-objelma. Helsinki: Kirkkohallitus.

Kirkon ympäristödiplomin käsikirja (2012). Kirkon ympäristödiplomin käsikirja 2012. Helsinki: Kirkkohallitus. https://evl.fi/ documents/1327140/49488564/KH_ diplomik\%C3\%A4sikirja_taitto_11+3. pdf/a1862247-4739-6b58-1e46-c29aae00787f?t=1551868610000 - viitattu 3.4.2020.

Kurssimateriaali. (2017). Ilmastonmuutos ja minä - Ahdistaako? -kurssin materiaali.
S. Saarimäki \& A. Morikawa. Ohjaajien hallussa.

Nikkanen, H. \& työryhmä. (2017). Hyvän sään aikana. Mitä Suomi tekee, kun ilmasto muuttaa kaiken? Helsinki: Into.

Ojala, M. (2012). How do children cope with global climate change? Coping strategies, engagement, and well-being. Journal of Environmental Psychology, 32(3):225233. https://doi.org/10.1016/j.jenvp.2012.02.004 - viitattu 1.4.2020.

Pihkala, P. (2019). Ilmastoabdistus ja sen kanssa eläminen. Helsinki: Mieli Suomen Mielentyerveysseura ry. https://mieli.fi/sites/ default/files/materials_files/ilmastoahdistusraportti-mieli2019-web.pdf - viitattu 1.8.2019.

Pihkala, P. (2017). Päin helvettiä? - ympäristöahdistus ja toivo. Helsinki: Kirjapaja.

Rakas ilmastonmuutos (2018). Rakas ilmas- 
tonmuutos. Kolumni. Aalto.fi, https:// www.aalto.fi/fi/uutiset/kolumni-rakas-ilmastonmuutos - viitattu 4.4.2020.

Sillanaukee, O. (2018). Zero Waste - jäähyväiset jätteille. Helsinki: S \& S.

Yle.fi. (2018). Ilmastoahdistus aiheuttaa vihaa, surua ja syyllisyyttä - Aalto-yliopisto tarjoaa opiskelijoille tukea ilmastonmuutoksen käsittelyyn ja muistuttaa toivosta. https://yle.fi/uutiset/3-10140284 - viitattu 1.8.2019.
Yle.fi. (2019a). Keskustele psykologin kanssa ilmastoahdistuksesta kello 9-11. https://yle.fi/uutiset/3-10764008 - viitattu 1.8.2019.

Yle.fi. (2019b). Surua, epätoivoa, pelkoa - ilmastoahdistus rajoittaa nuorten tulevaisuuden suunnitelmia. https://yle.fi/uutiset/3-10754435 - viitattu 1.8.2019. 